\title{
Did Directed Credit Impact the Effectiveness of Brazilian Monetary Policy in the Post Inflation-Target Period?
}

\author{
Marivia de Aguiar Nunes ${ }^{1 *}$, Augusto Mussi Alvim² \\ ${ }^{1}$ State Bank of Rio Grande do Sul (Banrisul), Porto Alegre, Brazil \\ ${ }^{2}$ Postgraduate Program in Economics, Pontifical University Catholic of Rio Grande do Sul (PUCRS), Porto Alegre, Brazil \\ Email: ^marivia.nunes@gmail.com
}

How to cite this paper: de Aguiar Nunes, M., \& Alvim, A. M. (2021). Did Directed Credit Impact the Effectiveness of Brazilian Monetary Policy in the Post Inflation-Target Period? Modern Economy, 12, 69-90. https://doi.org/10.4236/me.2021.121004

Received: November 20, 2020

Accepted: January 25, 2021

Published: January 28, 2021

Copyright () 2021 by author(s) and Scientific Research Publishing Inc. This work is licensed under the Creative Commons Attribution International License (CC BY 4.0).

http://creativecommons.org/licenses/by/4.0/

\section{(c) (i) Open Access}

\begin{abstract}
This essay aims to assess whether the effectiveness of monetary policy diminished after 2008 with the increase in the share of directed credit in the total credit in the Brazilian economy. For this reason, the monetary policy was only able to act on part of the credit existing in the economy. The main findings reveal that, up to September 2008, the pattern of interest rates influenced the directed credit, which corroborates with the research hypothesis. On the other hand, as of October 2008, it was found that only free credit was influenced by monetary policy and that the pattern of directed credit negatively affected the perception of risk in the Brazilian economy in the initial periods and over longer horizons. This suggests the policy of increasing the share of directed credit constitutes a strategy that does not contribute to the positive evolution of Brazil.
\end{abstract}

\section{Keywords}

Directed Credit, Credit, Monetary Policy, Interest Rate, Central Bank

\section{Introduction}

The stabilization of the Brazilian economy following the Real Plan in 1994 and the Inflation Targeting Regime (ITR) in 1999 led to the adoption of more predictable macroeconomic policies and the restructuring of the National Financial System, particularly in the banking sector, given, for example, the privatization of several state banks.

However, the Brazilian credit market maintains specific features that make the analysis of the effects of monetary policies more complex than other countries. 
As an example, the credit market can be divided into direct and non-direct transactions: direct credit has specific financing lines and subsidized interest rates for some sectors of the national economy (Veiga \& McCahery, 2019). As a result, the number of direct credits offered by Brazilian state banks, maintaining a relatively stable and exogenous money supply, which results in a lower capacity of monetary policy to change the credit market conditions (Silva, Paes, \& Bezerra, 2018).

As of 2003, it is seen a considerable expansion in credit concessions, especially free credit provided by private financial institutions, a move that saw an inflection in 2008, with the reduction of liquidity in private banks resulting from the international crisis. As the government at the time chose to adopt a countercyclical policy that would guarantee a high credit supply even in the face of adverse conditions in terms of liquidity, there was a significant increase in the share of directed credit in the total credit balance. This pattern can be attributed to the significant increase in the operations of the Banco Nacional de Desenvolvimento Econômico e Social (BNDES) and, to a lesser extent, real estate financing (Lundberg, 2011). As a result, the share of directed credit in the total credit balance increased by 19.3 percentage points from 30.8\% in September 2008 to $50.1 \%$ in May 2016.

Regarding the BNDES, it should be noted that the sources of financing used to make its operations viable are basically the resources of the Fundo de Amparo aoTrabalhador (FAT-Workers' Assistance Fund) and the National Treasury, with the transfers from the latter institution showing a considerable increase following the crisis of $2008^{1}$. This was possible because of the increase in the issuance (and subsequent sale) of federal debt securities, so that, to make BNDES funds available, the federal government increased its indebtedness, which further aggravated the already delicate situation of the Brazil's public accounts.

Regarding real estate financing, the increase seen after 2008 can be attributed to the improvement in income level, due to the previously heated labor market, but also to the reduction in the cost of such operations and the facilitation of the conditions for this type of credit (given the lengthening of the contraction deadlines for this debt, for example). At the time, these measures were adopted with the purpose of stimulating household consumption. However, the domestic recession started in 2014 and by significantly increasing the unemployment rate, it changed this situation, resulting in, among other developments, the tightening of conditions for real estate financing.

In addition to the increase in operations with directed credit, the interest rates are moderately lower than those for free credit, which tends to accompany movements in the basic interest rate. This is because operations with directed resources rely on subsidies (mostly paid by the interest rates of free operations), an element that, like the issuance of public debt securities, has a negative impact

${ }^{1}$ According to the BNDES (2017), in 2016, 80.8\% of BNDES funds came from the FAT (30.6\%) and the National Treasury (50.2\%). 
on the fiscal accounts.

Given this, the basic interest rate has an indirect influence on directed credit, through the deceleration (or expectation thereof) of economic activity and, consequently, a lower appetite for investment, precisely because the interest rate for the final borrower changes little. In this situation, basic interest rates affect domestic private demand less than they would in the absence of directed credit (Lima \& Barbosa, 2017).

According to Schwartsman (2011), "as the rates of the directed credit do not change in response to the Selic rate, the latter's movements should be broader in the face of shocks, since the credit channel is partially obstructed." In this context, one of the ways to increase the effectiveness of credit as a transmission channel for Brazilian monetary policy is through the elimination of subsidies to directed credit, which, on the one hand, would increase its cost, but on the other, would allow for an appreciable fall in the basic interest rate, which is high to compensate the losses arising from the reduced rates practiced for directed credit. Thus, the enhanced effectiveness of credit as a channel of transmission of monetary policy can occur in two ways: i) if the weight of the directed credit falls significantly, or b) if the interest rates for this type of credit approach market rates (Schwartsman, 2011; Borges, 2017).

In view of this, it is concluded that there is a strong relation between the volume of directed credit in the economy and the power of monetary policy. Therefore, it is important to note that, if reforms are implemented in the directed credit, in the context of falling basic interest rates, easing monetary conditions is likely to prove a more effective means of achieving the resumption of economic growth (containing any eventual expansion of activity with the potential of considerably raising price levels). In addition, policymakers increase the chances that the next cycle of interest rates rises, when it occurs, will be much less intense (Lima \& Barbosa, 2017).

In such circumstances, the main monetary policy instrument of the Brazilian Central Bank (CB), the basic interest rate, is incapable of significantly influencing directed credit, which in May 2016 represented $50.1 \%$ of total credit in the economy, which suggests a reduction in the effectiveness of the domestic monetary policy, whose operating power is restricted to half of the credit conceded in the country. In fact, the greater the share of directed credit in the total credit balance of the economy, the fewer effect changes in interest have on demand, given that this event causes a partial obstruction of the credit channel (that is, an obstruction of free credit, with market rates, due to an increase in the directed credit, with subsidized rates), an important means of transmitting monetary policy.

For purposes of comparison, it should be noted that the granting of subsidized or directed credit occurs in many countries. The Asian economies, for example, direct credit mainly to agriculture and to small industries, with the aim of stimulating economic growth; in turn, the United States uses credit primarily to 
reduce social inequality, increasing, for example, access to real estate financing (see, for example, Amsden \& Euh, 1993; Naastepad, 2001; Torres Filho, 2006). In Brazil, however, directed credit is largely granted to large companies (which have access to various sources of credit, especially the capital market) ${ }^{2}$, which is atypical in comparison with the other economies and is therefore, the motive behind the present study.

Specifically, in the case of the Brazilian economy, some studies attest to the importance of the credit channel as a transmitter of monetary policy. Souza Sobrinho (2003) presented empirical evidence of the importance of the bank lending channel in Brazil through descriptive analysis and econometric tests. In terms of results, the author, among other developments, confirms the relationship between the main indicators of the credit market, monetary policy and the real economy. The work of Takeda et al. (2005) evaluated the bank lending channel as a monetary policy transmitter, using monthly data from the balance sheets of Brazilian commercial banking institutions. In addition to short-term interest, the study considered another monetary policy instrument: compulsory deposits held on short-term and long-term savings. The researchers concluded that the lending channels in Brazil are not only influenced by interest rates, but also by the compulsory deposits, an effect that is more significant in larger financial institutions.

Looking for evidence for the existence of the lending channel as a transmitter of monetary policy in Brazil using a Vector Error Correction Model (VECM), Mello and Pisu (2010) found a negative relationship between Interbank Deposit Certificates (IDC) and the supply of bank loans for the period from December 1995 to June 2008. Therefore, short-term imbalances in the supply of loans would be corrected through changes in the IDC, suggesting that monetary policy plays a role in re-establishing balance in the credit market. Auel and Mendonça (2011), seeking to understand the credit channel as a transmitter of monetary policy in Brazil, analyzed data from 2002 to 2009 and, using three sets of Generalized Method of Moments (GMM) models, concluded that shocks in the interest rate are indirectly transmitted to the economy, through the credit channel.

The above-mentioned studies, although highly relevant, deal with credit in general, and do not consider, at least explicitly, that, in practice, Brazilian monetary policy has quite distinct effects on free and directed credit. To fill this gap, Bonomo and Martins (2016) analyzed the impact of directed credit and public banks on the monetary policy transmission mechanism through panel data that considered about 300,000 non-financial firms in the period 2006-2012, concluding that the credit channel loses effectiveness in the presence of directed credit.

In fact, all the above considerations show that the increase in the share of directed credit in the Brazilian economy motivates the study of the impacts of po-

\footnotetext{
${ }^{2}$ According to Lundberg (2011), the volume of credit granted to large industrial and infrastructure companies increased from R \$ 84.0 billion in 2007 to R \$ 181.4 billion in 2010, an increase of $116 \%$ in the period, compared to growth of only $30 \%$ in the period 2002-2007. In relative terms, credit directed to these corporations accounted for about $41 \%$ of the credit granted by the BNDES in 2010 .
} 
tential changes in the credit variables on the other macroeconomic variables, as well as monetary policy. Against this background, this study aims to assess if the effectiveness of monetary policy diminished after $2008^{3}$, with the increase in the share of the directed credit in the total credit in the Brazilian economy. The basic interest rate, in this interregnum, was only able to act on part of the credit existing in the economy (that is, on the free credit with market rates), which represents an important limitation to the scope of domestic monetary policy. This time window, which includes the mandates of Henrique Meirelles and Alexandre Tombini as presidents of the Brazilian Central Bank, was chosen because it has a considerable number of monthly observations and contains all the data necessary to enable the estimates. In addition, from 2003 to 2016, there was no change in the monetary policy regime, during which the ITR was in force. It is worth mentioning that currently the Inflation Target Regime remains the main monetary policy instrument in Brazil.

To achieve the proposed objective, after a brief review of the literature and the description of the methodology, the estimations are performed using a VAR model, which does not impose a rigid structure of causality between variables. Therefore, the VAR model allows relations to be drawn between them all; and impulse-response functions, following the Toda and Yamamoto (1995) procedure, while offering an increment to the work of Tomazzia and Meurer (2009). Through this procedure and the estimated model, it is possible to separately view the effects of free credit and directed credit shocks on Brazilian monetary policy, focusing on the latter, which is the main contribution of the present research in relation to previous studies that have focused on assessing the effects of total credit shocks on monetary policy. Finally, the last section contains the main conclusions of the study.

\section{Method and Data}

\subsection{Opening Remarks}

The difficulty of isolating the real effects that exert influence on monetary policy and of identifying its exogenous components, i.e., those that are not considered in the CB's reaction function ${ }^{4}$, are some of the main obstacles associated with conducting assessments of monetary policy.

Regarding the exogenous components of monetary policy, Bernanke and $\mathrm{Mi}$ hov (1998) point out there are two approaches to identifying them: 1) analysis of $\mathrm{CB}$ reports, declarations and actions, which provides more qualitative rather than quantitative results; and 2) the use, in econometric models, of the information considered by the Central Bank when determining monetary policy. The

\footnotetext{
${ }^{3}$ According to the BNDES (2017), $80.8 \%$ of BNDES funds came from the FAT $(30.6 \%)$ and the National Treasury (50.2\%) in 2016.

${ }^{4}$ The reaction function can be defined, according to Taylor (2000), as the mathematical rule (or formula) used by the monetary authority to determine, as accurately as possible, the circumstances in which its monetary policy instrument will be modified (in the case of the ITR, the instrument is the interest rate).
} 
second approach, in addition to being widely used in applied research, allows for the disaggregation of the endogenous and exogenous components of monetary policy, assuming, therefore, a quantitative character, which is why it will be used in the present study.

To achieve the research objective, a Vector Autoregressive (VAR) model was chosen because it does not impose a rigid structure of causality between variables and allows relationships to be drawn between all the variables (Bueno, 2011).

The VAR assumes the form:

$$
A X_{t}=B_{0}+\sum_{i=1}^{p} B_{i} X_{t-i}+B \varepsilon_{t}
$$

where $A$ is an $n \times n$ matrix that defines the contemporary constraints between the variables that constitute the vector $\left[n \times 1, X_{t}\right] ; X_{t}$ is the vector of endogenous variables; $B_{0}$ is the vector of constants $n \times 1 ; p$ is the number of lags; $B_{i}$ are the matrices $n \times n ; X_{t-i}$ is the vector of lagged values of $X_{t} ; B$ is a diagonal matrix $n \times n$ of standard deviations; and $\varepsilon_{t}$ is the vector $n \times 1$ of random errors or shocks $\left(\varepsilon_{t} \sim N(0, \Sigma)\right.$ and $E\left(\varepsilon_{t}, \varepsilon_{s}\right) \neq 0$, where $\left.t \neq s\right)$.

The above equation expresses the relations between the model's endogenous variables, which, in most situations, are the result of assumptions structured by the theory. Because of this, this equation is called structural. The shocks are also structural in that they individually affect each of the endogenous variables. In addition, such shocks are considered independent, since the interrelationships between one shock and another are indirectly captured by matrix A. Thus, the VAR residues are the result of a linear combination of contemporaneously uncorrelated exogenous shocks, in which it is impossible to identify the exogenous shock of each endogenous variable in the system.

This impossibility of identifying the shock means there is a need to obtain a method to make the contemporaneously uncorrelated residuals, which, in this study, is the Cholesky decomposition. This decomposition results in a series of matrices, one of which is a lower triangular matrix, demonstrating that the order of the variables is important. The problem is the ordering of the equations in the system to be estimated cannot be determined by statistical methods and is therefore arbitrarily performed by the researcher. Operationally, ordering means that the first variable affects all others contemporaneously, without being affected by the others; the second is affected only by the first, and affects all the others, and so on, and so the system is recursive. So, the objective of this model is to find the trajectory of the variable of interest (which, in this case, is the basic interest rate, although other variables are also analyzed) after a shock in the errors, that is, a structural shock. The present study aims to focus on assessing a shock in the volume of directed credit, even though other variables are also analyzed.

Regarding the assessment of the stationarity, causality and cointegration of the variables used, the treatment suggested by Toda and Yamamoto (1995) was adopted. For the researchers, in the case of the VAR, the unit-root and cointe- 
gration pre-tests, which are traditionally carried out when implementing the model, have low power, reducing the degree of reliability of the non-causality tests. In addition, regarding the cointegration, the tests used allow different specifications and, on account of this, return conflicting results (Marquetti, Koshiyama, \& Alencastro, 2009). Complementarily, in those cases where there is no cointegration, the variables are transformed to their first difference, which results in a loss of information, a disadvantage that is much discussed in the literature. Because of this, variables in level will be used in this study.

The procedure developed by Toda and Yamamoto (1995) is used to test Granger non-causality, which assumes that the variables are stationary. Nevertheless, the unit root tests, which enable testing of the stationarity of the series, such as the Augmented Dickey Fuller (ADF) and the Phillips Perron (PP) tests, have low assertiveness in regard to testing the alternative stationarity hypothesis and, because of this, are not recommended, particularly in the case of small samples (Toda \& Yamamoto, 1995). In addition, the cointegration tests, such as the Johansen test, also have limitations, since their results are very sensitive to the specifications adopted in the model, which tends to influence the results of the causality tests, making them more imprecise.

Toda and Yamamoto's (1995) method does not have the above-mentioned limitations, and one of its main advantages lies in the fact that it can be used in cointegrated, non-cointegrated series or in series with different integration orders, thus eliminating the need to conduct unit-root tests. In addition, this is one of the most recommended methods in the case of studies with relatively small samples (Yamada \& Toda, 1998). The procedure consists of conducting a Wald test to check the parameter constraints on a VAR model in levels and estimated using Ordinary Least Squares (OLS). According to the findings of Toda and Yamamoto (1995), the application of the Wald test to check the parameters constraints on an augmented VAR (k+e_max) in levels follows an asymptotic chi-square $\left(\chi^{2}\right)$, distribution, regardless of whether the system is cointegrated. In this case, $\mathrm{k}$ is the optimal number of lags in the model, and " $\mathrm{e}$-max" is the maximum integration order of the time series. In fact, the Wald test is implemented in the model's first $\mathrm{k}$ parameters the to check the validity of Granger's non-causality hypothesis. The other lagged parameters are not tested, and they serve only to ensure the presence of an asymptotic distribution $\chi^{2}$ (Marquetti, Koshiyama, \& Alencastro, 2009; Yamada \& Toda, 1998).

The procedure developed by Toda and Yamamoto (1995), although it is very useful, the procedure has limitations, since, as Mavrotas and Kelly (2001) point out, distortions may occur with small samples, as, in a system with many lags, the augmented Wald test would lose some of its qualities. Therefore, Mavrotas and Kelly (2001) suggest using the bootstrap method with the residues to increase the power of the test and confirm the robustness of the results found.

Regarding the present study, it should be noted that the focus is not on the analysis of the VAR coefficients, since this model is by its nature super- parame- 
terized. Using the VAR, it is possible to calculate impulse-response functions, which are the focus of this study, as they allow reveal how one variable responds to one impulse (or shock) in another.

\subsection{Data and Model Specification}

The variables used in the estimation are shown in Table 1 . The sample used in the estimations began in January 2003, and ended in May 2016, a period in which the monetary policy was constant in qualitative terms, since, in this interregnum, there was no change in the monetary policy regime, the ITR in force. Another justification for the choice is that this time window, which includes the mandates of Henrique Meirelles and Alexandre Tombini as presidents of the Brazilian CB, includes numerous monthly observations and contains all the data necessary to enable the estimations.

It should also be noted that this time window was chosen to facilitate the identification of any change in the pattern of the directed credit as from 2008, which was operationalized through the retropolation, from January 2003 to February 2007, of the time series of directed and free credit. This was accomplished using the discontinued series of these variables, which are found in the Time Series Manager System of the Central Bank.

As for VAR, firstly, the work of Tomazzia and Meurer (2009) is followed, estimating a General Model (GM), which considers: 1) the CB's main monetary policy instrument (the basic rate, as defined in Table 1 as the SELIC). In addition, 2) the information to which the monetary authority reacts: the product (defined in Table 1 as the GDP), the price level (defined in Table 1 as the BCPI), the exchange rate (defined in Table 1 as ER) and credit variables (defined in Table 1 as FC and DC).

This model follows the specification of research conducted considering the American economy, such as Bernanke and Gertler (1995) and Christiano et al. (1999). In addition, the exchange rate was included, in line with studies conducted regarding the Brazilian economy-see, for example, Minella (2003) and Arquette and Jayme-Jr. (2003) - and for other open economies-such as Dedola and Lippi (2005). The credit variables, CL and CD, were included in order to separate the effects of shocks on such variables, which is an enhancement on the work of Tomazzia and Meurer (2009). Thus, in this study, the main methodological contribution is the fact that, through the estimations, it is possible to separately check the effects of the shocks of free credit and directed credit on Brazilian monetary policy.

The ordering of the variables used in the Cholesky decomposition to generate the impulse-response functions, which also followed Tomazzia and Meurer (2009), was: GDP, IPCA, SELIC, FC, DC and ER. That ordering follows theoretical assumptions similar to those adopted in Minella (2003), Christiano et al. (1999) and Dedola and Lippi (2005). In these studies, the level of production does not respond contemporaneously to the other variables, since the production 
Table 1. Name, description and source of the variables used.

\begin{tabular}{|c|c|c|c|}
\hline Variable & Acronym & Description & Source \\
\hline $\begin{array}{l}\text { Monetary Policy } \\
\text { Instrument }\end{array}$ & SELIC & $\begin{array}{l}\text { Interest rate-accumulated Selic in } \\
\text { the annualized month base } 252 \\
\text { (\% per annum). }\end{array}$ & BCB (2017) \\
\hline $\begin{array}{l}\text { Indicator of eco- } \\
\text { nomic activity }\end{array}$ & GDP & $\begin{array}{l}\text { Monthly GDP from the Fundação } \\
\text { Getúlio Vargas (FGV) }\end{array}$ & FGV (2017) \\
\hline Exchange rate & ER & $\begin{array}{l}\text { Exchange Rate-Free-US Dollar } \\
\text { (purchase)-End of Period-Monthly } \\
\text { (R\$/US\$)-Code } 3695\end{array}$ & BCB (2017) \\
\hline Domestic Inflation & BCPI & $\begin{array}{l}\text { Brazilian National Consumer Price } \\
\text { Index-IPCA (index number based } \\
100=\text { Dec/93) }\end{array}$ & IBGE (2017) \\
\hline Expected inflation & EI & $\begin{array}{l}\text { Expectation of the official inflation rate } \\
\text { (IPCA)-expected for the end of the } \\
\text { following month at the beginning of } \\
\text { the current month-monthly median } \\
\text { (\% per month). }\end{array}$ & BCB (2017) \\
\hline Free Credit & FC & $\begin{array}{l}\text { Total credit balance with free credit } \\
\text { (R } \$ \text { million, deflated by the IPCA)_Code } \\
12,130 \text { (from Jan/2003 to Feb/2007, } \\
\text { whose percentage variation was used to } \\
\text { retropolate using code } 20,542 \text { ) and code } \\
\text { 20,542/from Mar/2007 to May/2016). }\end{array}$ & BCB (2017) \\
\hline Directed credit & $\mathrm{DC}$ & $\begin{array}{l}\text { Total credit balance with directed credit } \\
\text { (R } \$ \text { million, deflated by the IPCA)_Code } \\
7524 \text { (from Jan/2003 to Feb/2007, whose } \\
\text { percentage variation was used to } \\
\text { retropolate using code 20593) } \\
\text { and code } 20593 \text {. }\end{array}$ & BCB (2017) \\
\hline $\begin{array}{l}\text { Long-term interest } \\
\text { rate }\end{array}$ & SWAP & $\begin{array}{l}\text { Reference rate-swaps-pre-fixed } \\
\text { DI-360 days-end of period } \\
\text { (\% per year). }\end{array}$ & $\begin{array}{c}\text { IPEADATA } \\
(2017)\end{array}$ \\
\hline Country Risk & EMBI & $\begin{array}{l}\text { EMBI +/Brazil-risk end of period } \\
\text { (in base points). }\end{array}$ & $\begin{array}{l}\text { JP Morgan } \\
\text { (2017) }\end{array}$ \\
\hline External Inflation & CPI & $\begin{array}{l}\text { All Commodity Price Index, includes } \\
\text { both Fuel and Non-Fuel Price Indexes } \\
\text { (index number based on } 100=2005 \text {, } \\
\text { modified for natural logarithm). }\end{array}$ & FMI (2017) \\
\hline $\begin{array}{l}\text { International basic } \\
\text { interest rate }\end{array}$ & FFR & Effective Federal Funds Rate (\% pa). & $\begin{array}{l}\text { Fed St. Louis } \\
\quad(2017)\end{array}$ \\
\hline
\end{tabular}

Source: Elaborated by the authors based on Tomazzia and Meurer (2009).

decisions and, consequently, their effects on the final production, occur with some degree of lag, which is greater than the periodicity of the series used in this 
research, which is monthly. The inflation can only be influenced contemporaneously by production, given that the goods market is dynamic and consequently contains price adjustments resulting from changes in supply and demand with a period of less than one month. The interest rate responds contemporaneously to the product and inflation, to the extent that the monetary authority has relevant informational content on the behavior of such variables, incorporating them in their monetary policy decisions. The credit variables, considered dynamic, respond quickly, and respond to all the other variables mentioned above. Moreover, the exchange rate is the most dynamic in the system, and responds contemporaneously to any shock to the other variables.

In addition to the general model, two alternative models were estimated, also following Tomazzia and Meurer (2009) and, as in the General Model (GM), some of the variables were modified and removed:

- Open Economy Model (OEM): this model demonstrates the main relationships existing in a small open economy, following Cushman and Zha (1997). In addition to the variables considered in the General Model (GM), the country risk is defined as an endogenous variable (defined in Table 1 as EMBI), which objectively expresses the risk credit to foreign investors when investing in Brazil (BCB, 2009). In terms of ordering, this variable was placed last. The exogenous variables, namely, the external model (defined in Table 1 as CPI) and the United States interest rate (defined in Table 1 as FFR) were added to the General Model (GM), which are not influenced by the variables related to the Brazilian economy, but rather exert influence upon it. According to Tomazzia and Meurer (2009), external inflation, which can be considered a measure of external supply shocks, is important information to improve the estimation of the CB's reaction function and, consequently, the exogenous shock of monetary policy on domestic prices. The United States' basic interest rate, in turn, indicates the opportunity cost of foreign capital, which is relevant because it considers the relationship between the domestic interest rate and the exchange rate under the open interest rate parity (OIRP).

- Expectations Model (EM): in this estimation, besides the variables of the General Model (GM), the expectations for the interest rate and the official inflation are considered, thus capturing the effect generated by the expectation channel as a transmitter of the monetary policy to be captured. In practical terms, the term structure of the interest rate, defined in Table 1 as SWAP, was used. This variable was ordered immediately after the basic interest rate since it is affected contemporaneously by the latter. The inflation expectations variable, defined in Table 1 as EI, is inserted before the price level in the ordering, since it represents the expectation for the IPCA at the beginning of the current month in relation to inflation at the end of the following month. Table 2 summarizes the Cholesky decomposition and the endogenous and exogenous variables in each model: 
Table 2. Endogenous and exogenous variables of each model, listed according to the adopted Cholesky decomposition.

\begin{tabular}{ccc}
\hline Model & Endogenous variables & Exogenous variables \\
\hline GM & GDP, IPCA, SELIC, FC, DC and ER & None \\
OEM & GDP, IPCA, SELIC, FC, DC and ER and EMBI & CPI and FFR \\
EM & GDP, IPCA, SELIC, SWAP, FC, DC and ER & None \\
\hline
\end{tabular}

a. The further to the left the more endogenous is the variable. Source: Elaborated by the authors based on Tomazzia and Meurer (2009).

\section{Results and Discussion}

\subsection{Assessing the Stationarity of the Series and Defining the VAR Models to Be Estimated}

Before estimating the VARs, the three models were subjected to a Chow test to see whether a structural break occurred when the directed credit was placed as a dependent variable. The results showed for the three models showed there was a structural break in October 2008. Therefore, the sample will be divided into two subsamples: 1) from January 2003 to September 2008 (69 observations); and 2) from October 2008 to May 2016 (92 observations). In both cases, the number of observations is still adequate to carry out the estimates.

Then, we defined the maximum order of integration (e_max) of all the variables to be used in the models, by conducting the Augmented Dickey Fuller (ADF) test in the two sub-samples mentioned above. The maximum order of integration for sub-sample 1 (Jan/2003 to Sep/2008) was 2, whereas for sub-sample 2 (Oct/2008 to May/2016), the maximum integration order was 1 , as can be seen in Table 3.

The next step was to set the VARs in level and determine their optimal number of lags $(k)$ based on the information criteria, by analyzing the Schwarz criterion. In terms of results, this criterion indicated that, in both sub-samples 1 and 2 , for the three VAR models estimated in this research, the order of lag 1 is the most adequate, so that $\operatorname{VAR}(k)=\operatorname{VAR}(1)$.

\subsection{Checking the Stability of the Models and Testing Causality in the Granger Sense}

Table 4 shows that the Wald tests indicated causalities that are well-known in the economic literature (notably EI $\leftrightarrow$ IPCA, for example) as well as less studied causalities.

After the steps described in the previous section, the stability of the VAR (1) models, particularly the question of cointegration, was checked using the Engle-Granger test, to see whether the regression residuals are cointegrated. As none of the VAR (1) models presented cointegration problems, the following additions were made: 1) two lags, in the case of the model to be estimated based on sub-sample 1 (obtained when the system's maximum integration order was confirmed); and 2) one lag in the case of the model to be estimated using 
Table 3. Results of the unit-root tests of the variables used in the estimates.

\begin{tabular}{|c|c|c|c|c|c|c|}
\hline \multirow[b]{2}{*}{ Series } & \multicolumn{3}{|c|}{ Sub-sample 1: Jan/2003 to Sep/2008 } & \multicolumn{3}{|c|}{ Sub-sample 2: Oct/2008 to May/2016 } \\
\hline & Level & p-value & $\begin{array}{c}\text { Order of } \\
\text { integration }\end{array}$ & Level & p-value & $\begin{array}{c}\text { Order of } \\
\text { integration }\end{array}$ \\
\hline Selic & -0.011894 & 0.003 & $\mathrm{I}(0)$ - no drift & -0.23001 & 0.000526 & $\begin{array}{l}\mathrm{I}(1)-\text { no } \\
\text { drift }\end{array}$ \\
\hline GDP & -1.0981 & $8.49 \mathrm{E}-01$ & $\mathrm{I}(1)$-drift & -0.65764 & $7.937 \mathrm{E}-01$ & $\begin{array}{c}\mathrm{I}(1)-\text { no } \\
\text { drift }\end{array}$ \\
\hline ER & -1.07007 & $1.44 \mathrm{E}-01$ & $\mathrm{I}(1)$ - drift & -0.85469 & $2.797 \mathrm{E}-02$ & $\begin{array}{c}\mathrm{I}(1)-\text { no } \\
\text { drift }\end{array}$ \\
\hline IPCA & -0.435184 & $1.59 \mathrm{E}-01$ & $\mathrm{I}(0)$ - drift & -0.33984 & 0.000836 & $\mathrm{I}(0)-\mathrm{drift}$ \\
\hline EI & 0.629357 & $9.44 \mathrm{E}-01$ & $\begin{array}{l}\mathrm{I}(0)-\mathrm{drift} \\
\text { and trend }\end{array}$ & -0.25109 & 0.007482 & $\mathrm{I}(0)$ - drift \\
\hline $\mathrm{FC}$ & -1.29605 & $1.93 \mathrm{E}-05$ & $\mathrm{I}(2)$ - no drift & -0.988043 & $8.112 \mathrm{E}-01$ & $\begin{array}{l}\mathrm{I}(1)-\mathrm{drift} \\
\text { and trend }\end{array}$ \\
\hline DC & -0.558406 & 0.0001 & $\mathrm{I}(1)$-drift & -0.557242 & $2.282 \mathrm{E}-01$ & $\begin{array}{l}\mathrm{I}(1)-\mathrm{drift} \\
\text { and trend }\end{array}$ \\
\hline SWAP & -0.095061 & 0.000973 & $\mathrm{I}(0)$ - drift & -0.742944 & $2.462 \mathrm{E}-01$ & $\begin{array}{c}\mathrm{I}(1)-\text { no } \\
\text { drift }\end{array}$ \\
\hline EMBI & -0.119647 & $1.14 \mathrm{E}-01$ & $\mathrm{I}(0)$ - drift & -0.85501 & $8.152 \mathrm{E}-03$ & $\begin{array}{c}\mathrm{I}(1)-\text { no } \\
\text { drift }\end{array}$ \\
\hline CPI & -0.55823 & $1.11 \mathrm{E}-01$ & $\mathrm{I}(1)-$ no drift & -0.495458 & $2.958 \mathrm{E}-01$ & $\begin{array}{c}\mathrm{I}(1)-\text { no } \\
\text { drift }\end{array}$ \\
\hline FFR & -0.308943 & 0.000853 & $\mathrm{I}(1)$ - drift & -0.315556 & $1.285 \mathrm{E}-07$ & $\begin{array}{c}\mathrm{I}(0) \text { - no } \\
\text { drift }\end{array}$ \\
\hline
\end{tabular}

Source: Elaborated by the authors.

sub-sample 2. The result was: 1) one model VAR (3), in the case of sub-sample 1; and 2) one VAR (2) in the case of sub-sample 2. Finally, the Wald test was carried out to check the hypothesis of non-causality in the Granger sense. The results are shown in Table 4, where Granger's causalities are presented based on Wald's tests for the estimated models.

It is worth remembering that in this research the focus will be to analyze the causal relationships that involve directed credit, a variable associated with the objective of this study, i.e., to determine whether the effectiveness of monetary policy diminished after 2008, with the increase in share of directed credit in the total credit balance of the Brazilian economy. This analysis will be carried out in the next section, which includes the impulse-response functions involving the DC.

\subsection{Analysis of Causalities and Impulse-Response Functions Involving DC}

Before proceeding, however, it should be noted that in Table 4, neither the any of the subsamples nor any of the models show the existence of causality between 
Table 4. Granger causalities based on the wald tests for the estimated VARs*.

\begin{tabular}{|c|c|c|}
\hline Model & $\begin{array}{l}\text { Sub-sample 1: VAR (3) } \\
\text { (Jan/2003 to Sep/2008) }\end{array}$ & $\begin{array}{l}\text { Sub-sample } 2 \text { : VAR (2) } \\
\text { (Oct/2008 to May/2016) }\end{array}$ \\
\hline GM & $\begin{array}{c}\text { SELIC } \rightarrow \text { GDP } \\
\text { SELIC } \leftrightarrow \text { IPCA } \\
\text { DC } \rightarrow \text { IPCA } \\
\text { ER } \rightarrow \text { IPCA } \\
\text { GDP } \rightarrow \text { ER }\end{array}$ & $\begin{array}{c}\mathrm{SELIC} \leftrightarrow \rightarrow \mathrm{GDP} \\
\mathrm{DC} \rightarrow \mathrm{GDP} \\
\mathrm{FC} \rightarrow \mathrm{SELIC} \\
\mathrm{IPCA} \rightarrow \mathrm{FC} \\
\mathrm{DC} \rightarrow \mathrm{FC} \\
\mathrm{ER} \rightarrow \mathrm{FC} \\
\mathrm{IPCA} \rightarrow \mathrm{DC} \\
\mathrm{ER} \rightarrow \mathrm{DC} \\
\mathrm{GDP} \rightarrow \mathrm{ER} \\
\mathrm{SELIC} \rightarrow \mathrm{ER}\end{array}$ \\
\hline OEM & $\begin{array}{c}\text { SELIC } \leftrightarrow \text { IPCA } \\
\text { ER } \rightarrow \text { IPCA } \\
\text { DC } \leftrightarrow \text { SELIC } \\
\text { ER } \rightarrow \text { SELIC } \\
\text { GDP } \rightarrow \text { FC } \\
\text { DC } \leftrightarrow \text { FC } \\
\text { ER } \rightarrow \text { DC } \\
\text { FC } \rightarrow \text { ER } \\
\text { GDP } \rightarrow \text { EMBI } \\
\text { SELIC } \rightarrow \text { EMBI } \\
\text { ER } \rightarrow \text { EMBI }\end{array}$ & $\begin{array}{c}\mathrm{SELIC} \rightarrow \mathrm{GDP} \\
\mathrm{DC} \rightarrow \mathrm{GDP} \\
\mathrm{GDP} \rightarrow \mathrm{SELIC} \\
\mathrm{FC} \rightarrow \mathrm{SELIC} \\
\mathrm{IPCA} \rightarrow \text { FC } \\
\mathrm{DC} \rightarrow \mathrm{FC} \\
\mathrm{IPCA} \rightarrow \mathrm{DC} \\
\mathrm{SELIC} \rightarrow \mathrm{ER} \\
\mathrm{FC} \rightarrow \mathrm{ER} \\
\mathrm{EMBI} \rightarrow \mathrm{ER} \\
\mathrm{SELIC} \rightarrow \mathrm{EMBI} \\
\text { FC } \rightarrow \text { EMBI } \\
\mathrm{DC} \rightarrow \text { EMBI }\end{array}$ \\
\hline EM & $\begin{array}{c}\mathrm{EI} \rightarrow \mathrm{GDP} \\
\mathrm{ER} \rightarrow \mathrm{EI} \\
\mathrm{ER} \rightarrow \mathrm{IPCA} \\
\mathrm{EI} \rightarrow \mathrm{SELIC} \\
\mathrm{SWAP} \leftrightarrow \rightarrow \text { SELIC } \\
\mathrm{ER} \rightarrow \text { SELIC } \\
\mathrm{GDP} \rightarrow \text { SWAP } \\
\mathrm{ER} \rightarrow \mathrm{DC} \\
\mathrm{GDP} \rightarrow \mathrm{ER}\end{array}$ & $\begin{array}{c}\mathrm{DC} \rightarrow \mathrm{GDP} \\
\mathrm{IPCA} \leftrightarrow \rightarrow \mathrm{EI} \\
\mathrm{IPCA} \rightarrow \text { SELIC } \\
\mathrm{SWAP} \leftrightarrow \rightarrow \text { SELIC } \\
\mathrm{DC} \rightarrow \text { SWAP } \\
\mathrm{IPCA} \rightarrow \mathrm{FC} \\
\mathrm{DC} \rightarrow \mathrm{FC} \\
\mathrm{ER} \rightarrow \mathrm{FC} \\
\mathrm{IPCA} \rightarrow \mathrm{DC} \\
\mathrm{ER} \rightarrow \mathrm{DC} \\
\mathrm{GDP} \rightarrow \mathrm{ER}\end{array}$ \\
\hline
\end{tabular}

a. Note: $\leftrightarrow$ indicates bidirectional causality. Source: Elaborated by the authors.

SELIC and DC in any sense, which corroborates the research hypothesis, that monetary policy is unable to influence directed credit.

As mentioned above, this section presents the analysis of the impulse- response functions involving DC, the graphs of which are in Appendix A. In terms of interpretation, each impulse-response graph indicates the response of a variable, as a percentage (except for the SELIC variable, which should be read in percentage points), to a shock of one standard deviation in another variable. It should be noted that all the impulse-response functions were obtained considering 1) the Cholesky ordering described in the research methodology section; and 2) a 24-month forecast horizon. 


\subsubsection{Impulse-Response Functions Derived from Variables Caused by DC}

Observing Table 4 and considering sub-sample 1, one can see that DC causes IPCA in the GM and there is two-way causality with the SELIC and DC in the OEM. In turn, in sub-sample 2, considering the GM, DC causes GDP and CL; while in the OEM, it causes GDP, FC and EMBI; and, finally, in the EM it causes GDP, SWAP and FC. It should be noted that in sub-sample 2 and in all three estimated models, DC causes GDP and FC, suggesting these relations are quite relevant. Furthermore, DC is caused by IPCA in these same criteria, which again did not occur in sub-sample 1, demonstrating a change in the estimated VAR parameters for each sub-sample. It can also be seen that, in sub-sample 2, both in the GM and in the OEM, FC causes SELIC, suggesting that FC influences monetary policy, an outcome that, was expected in an economic sense, being merely confirmed by the estimated models.

Regarding the impulse-response functions derived from the variables caused by DC, we opted to analyze only the most relevant relations that were consistent with the objective of this study. Regarding this, in the GM, Figure A1 (Appendix A) reveals that the DC ratio causes GDP to occur in sub-sample 2, while that is not the case in sub-sample 1, so that, as of October 2008, it can be said that the increase in directed credit was predominantly negative for the product of the Brazilian economy. This constitutes an important result, since, in theory, the concession of this type of credit should act in the opposite direction to that found with this estimation.

Further, considering the GM, Figure A2 (Appendix A) shows that the DC ratio causes CL to occur in sub-sample 2, while that is not the case in sub-sample 1 , so that, as of October 2008, it can be said that the increase in directed credit was predominantly negative (or exercised neutral influence) on free credit. This outcome is conformed to economic sense, since the opportunity cost of granting greater volumes of directed credit corresponds to giving up a portion of the free credit concession.

Regarding the OEM, Figure A3 (Appendix A) reveals that the DC ratio causes SELIC to occur in sub-sample 1, while that is not the case in sub-sample 2, so that until September 2008, the pattern of directed credit contributed to the reduction in the interest rate, whereas, from there, the relationship between these two variables was not significant.

Also, in the OEM, observing Figure A4 (Appendix A) one can see the DC ratio causes FC in both sub-sample 1 and sub-sample 2, so that a change of behavior can be seen in these two periods. In sub-sample 1, the pattern of directed credit resulted, except in the initial periods, in increase free credit, whereas, in sub-sample 2, the initial effect of the pattern of directed credit was negative for free credit, and continued to be negative throughout the analysis horizon, although in a somewhat reduced magnitude. This demonstrates that, as of October 2008 , with the increase in directed credit, free credit was penalized, which is linked to the issue of the cost of opportunity of granting credit, mentioned 
above.

Also, in the OEM, observing Figure A5 (Appendix A) on can sees the DC ratio causes EMBI in sub-sample 2, while that is not the case in sub-sample 1, so that, from October 2008, it can be stated that the pattern of directed credit negatively affected the perception of risk in the Brazilian economy in the initial periods. Over longer horizons were slightly negative again, suggesting the policy of increasing the participation of directed credit constituted an event which, in the view of the markets, did not contribute to the positive evolution of the Country.

On the other hand, in the EM, Figure A6 (Appendix A) reveals that the DC ratio causes GDP to occur in sub-sample 2, while that is not the case in subsample 1, so that, from October 2008, the pattern of directed credit overwhelmingly contributed to the fall in the product in the Brazilian economy. The same result as found in the GM, the justification of which is discussed above.

Further, in the EM, Figure A7 (Appendix A) shows the DC ratio only causes FC in sub-sample 2, so that from 2008, the increase in the directed credit was negative for free credit over the entire horizon analysis, so that, with the increase in the directed credit, free credit was penalized, the same conclusion obtained in the GM and OEM.

\subsubsection{Impulse-Response Functions Derived from the Variables That Cause DC}

According to Table 4, it can be noted that, regarding the variables that cause DC, considering sub-sample 1, ER causes DC in the GM and in the EM. In sub-sample 2, considering the GM, IPCA and ER cause DC; in the OEM, IPCA causes DC; and in the EM, IPCA and ER cause DC.

Regarding the impulse-response functions that derive from the variables that cause DC, only the relationships most relevant to and consistent with the objective of this article were analyzed. Accordingly, in the OEM, Figure A8 (Appendix A) shows the SELIC ratio causes DC only in sub-sample 1, while that is not the case in sub-sample 2. So, until September 2008, the pattern of interest rates influenced directed credit, so that, from then on, the relationship between these two variables was not significant, demonstrating that the interest rate did not influence directed credit after a significant increase in the latter, the main hypothesis of this research.

Further, regarding the OEM, Figure A9 reveals the FC ratio only causes DC in sub-sample 1 , so that, in this period, the pattern of free credit influenced that of directed credit, whereas in sub-sample 2 this did not occur.

\section{Conclusion}

The monetary policy decisions made by the $\mathrm{CB}$ come about through changes in the short-term interest rate, and such changes exert influence on the product of the economy through transmission channels, among them those of credit. In this sense, there has been an important transformation in the Brazilian economy over the last decade. The increase in the share of directed credit in the total cre- 
dit balance of the economy, which increased from 30.8\% in September 2008 to $50.1 \%$ in May 2016, a shift that can be mainly attributed to the significant increase in operations by the BNDES and real estate financing concessions.

It should be noted that the interest rates of credit operations with directed resources are reasonably lower than those of free credit, which tend to accompany shifts in basic interest rates. In these circumstances, the main monetary policy instrument of the Central Bank of Brazil, the basic interest rate, is capable of significantly influencing directed credit, which in May 2016 represented 50.1\% of the total credit in the economy. This suggests a reduction in the effectiveness of the domestic monetary policy, the power of which is restricted to free credit, which accounts for half of the credit granted in the country.

Against this background, the objective of this essay was to assess whether the effectiveness of monetary policy diminished after 2008, with the increase in the share of directed credit in the total credit balance of the Brazilian economy. To do so, after a brief review of the literature and an exposition of the methodology used in this work, the estimations were performed, which were conducted using a VAR model and impulse-response functions, following the procedure Toda and Yamamoto's (1995), while enhancing the work of Tomazzia and Meurer (2009).

The difficulties of isolating the real effects that exert influence on monetary policy and of identifying its exogenous components, that is, those not considered in the $\mathrm{CB}$ reaction function, are some of the main obstacles associated with attempts to assess monetary policy. Therefore, in this study we opted to use an econometric model to identify the influence of credit on monetary policy. By doing so, it was possible separately to analyze the effects of free credit and directed credit shocks on Brazilian monetary policy, while focusing on the latter. These are the main contribution of this study, since previous studies have only evaluated the effects of total credit shocks on monetary policy.

The model chosen for this study was that of Autoregressive Vectors (VAR), which does not impose a rigid structure of causality between the variables, thus allowing relations to be drawn between all of them. Here, the focus of this study was not the analysis of the VAR coefficients but rather the impulse-response functions resulting from their estimation, which allowed us to identify how one variable responds to an impulse (or shock) in another. In the case of this study, the main objective was to analyze how the variables used in the estimated models responded to a directed credit shock, and how the directed credit responded to a shock in these same variables.

In terms of modeling, three models were estimated: 1) a General Model (GM), which considered the basic interest rate, the product, the price levels, the exchange rate and free and directed credit to be endogenous variables; 2) an Open Economy Model (OEM), which took into account, in addition to the variables in the GM, Country Risk as an endogenous variable; and external inflation and the USA interest rate as exogenous variables; and 3) an Expectations Model (EM), 
which considered, in addition to the variables in the GM, the expectations for the interest rate and for official inflation, both endogenous.

Regarding the results, we started by identifying the most important causal relations for the purpose of the research, that is, those involving DC. After which, an analysis of the most relevant impulse-response functions involving this variable was carried out. In terms of interpretation, each graph of the impulse- response functions indicates the response of a variable, as a percentage (except in the case of the SELIC variable, which should be read in percentage points), to a shock of a standard deviation in another variable.

Regarding the study's main findings, it was observed that until September 2008, the pattern of directed credit contributed towards a reduction in the interest rate, which ceased to occur thereafter. Also, during this period, interest rate dynamics influenced the directed credit, demonstrating that the interest rate had no influence on the directed credit after the relevant increase of the latter, which occurred from the end of 2008. This aspect corroborates with the main hypothesis of this research, that is, that from 2008 only free credit changes when there is a change in Brazilian monetary policy.

In turn, as of October 2008, the increase in directed credit was predominantly negative for the Brazilian economy, which is another important study finding, since, in theory, concession of this type of credit should act in the opposite direction to that found with this estimation. In addition, the increase in direct credit was predominantly negative (or exerted a neutral influence) on free credit, an outcome that conforms to economic sense, since the opportunity cost of granting higher volumes of directed credit corresponds to giving up a portion of the concession of free credit. Further in this period, only free credit was found to be influenced by the monetary policy and that pattern of directed credit negatively affected the perception of risk in the Brazilian economy in the initial periods and in longer horizons. This suggests that the policy of increasing the participation of directed credit constitutes an event that, in the view of the markets, does not contribute to the positive evolution of the Country.

\section{Conflicts of Interest}

The authors declare no conflicts of interest regarding the publication of this paper.

\section{References}

Amsden, A., \& Euh, Y. (1993). South Korea's Financial Reforms: Goodbye Financial Repression (Maybe), Hello New Institutional Restraints. World Development, 21, 379-390. https://doi.org/10.1016/0305-750X(93)90151-X

Arquette, L., \& Jayme-Jr, F (2003). Política monetária, preços e produto no Brasil (1994-2002): Uma aplicação de vetores auto-regressivos. XXXI Encontro Nacional de Economia da ANPEC, Porto Seguro, 9-12 December 2003, 1-20.

Auel, M. C., \& Mendonça, H. F. (2011). Macroeconomic Relevance of Credit Channels: Evidence from an Emerging Economy under Inflation Targeting. Economic Modelling, 
28, 965-979. https://doi.org/10.1016/j.econmod.2010.11.012

Banco Nacional de Desenvolvimento Econômico e Social. Fontes de Recursos. https://www.bndes.gov.br/wps/portal/site/home/relacoes-com-investidores/fontes-de-r ecursos

Bernanke, B., \& Gertler, M. (1995). Inside the Black Box: The Credit Channel of Monetary Policy Transmission. Journal of Economic Perspectives, 9, 27-48. https://doi.org/10.1257/jep.9.4.27

Bernanke, B., \& Mihov, I. (1998). Measuring Monetary Policy. Quarterly Journal of Economics, 103, 869-902. https://doi.org/10.1162/003355398555775

Bonomo, M., \& Martins, B. (2016). The Impact of Government-Driven Loans in the Monetary Transmission Mechanism: What Can We Learn from Firm-Level Data? Banco Central Do Brasil, Working Paper Series No. 419.

Borges, B. L. (2017). Como reduzir o juro estrutural no Brasil: O caminho das pedras. Blog do Instituto Brasileiro de Economia (IBRE), March.

http://blogdoibre.fgv.br/posts/como-reduzir-o-juro-estrutural-no-brasil-o-caminho-da s-pedras

Bueno, R. L. S. (2011). Econometria de séries temporais. São Paulo: Cengage Learning.

Christiano, L. J., Einchenbaum, M., \& Evans, C. (1999). Monetary Policy Shocks: What Have We Learned and to What End? In L. J. Christiano, M. Eichenbaum, \& C. L. Evans (Eds.), Handbook of Macroeconomics (pp. 65-148). Amsterdam: Elsevier Science. https://doi.org/10.3386/w6400

Cushman, D. O., \& Zha, T. (1997). Identifying Monetary Policy in a Small Open Economy under Flexible Exchange Rates. Journal of Monetary Economics, 39, 433-448. https://doi.org/10.1016/S0304-3932(97)00029-9

Dedola, L., \& Lippi, F. (2005). The Monetary Transmission Mechanism: Evidence from the Industries of Five OECD Countries. European Economic Review, 49, 1543-1569. https://doi.org/10.1016/j.euroecorev.2003.11.006

Lima, D. C., \& Barbosa, F. H. (2017). Direcionamento de crédito e eficiência da política monetária no Brasil. Destaque Depec Bradesco, ano XIV, n. 170, February.

Lundberg, E. L. (2011). Bancos Oficiais e Crédito Direcionado o que diferencia o mercado de crédito brasileiro? Banco Central do Brasil (pp. 1-39). Trabalho para discussão no 258, November.

Marquetti, A. A., Koshiyama, D., \& Alencastro, D. (2009). O aumento da lucratividade expande a acumulação de capital? Uma análise de causalidade de Granger para países da OCDE. Revista de Economia Contemporânea (REC), Rio de Janeiro, 13, 367-390. https://doi.org/10.1590/S1415-98482009000300001

Mavrotas, G., \& Kelly, R. (2001). Old Wine in New Bottles: Testing Causality between Savings and Growth. The Manchester School, 69, 97-105. https://doi.org/10.1111/1467-9957.69.s1.6

Mello, L., \& Pisu, M. (2010). The Bank Lending Channel of Monetary Transmission in Brazil: A VECM Approach. The Quarterly Review of Economics and Finance, 50, 50-60. https://doi.org/10.1016/j.qref.2009.09.006

Minella, A. (2003). Monetary Policy and Inflation in Brazil (1975-2000): A VAR Estimation. Revista Brasileira de Economia, 57, 605-635. https://doi.org/10.1590/S0034-71402003000300005

Naastepad, C. W. M. (2001). The Macro-Economic Effects of Directed Credit Policies: A Real-Financial CGE Evaluation for India. Development and Change, 32, 491-520. https://doi.org/10.1111/1467-7660.00214 
Schwartsman, A. (2011). Sobre Jabutis e Jabuticabas. Jornal Valor Econômico, July.

Silva, I. E. M., Paes, N. L., \& Bezerra, J. F. (2018). Evidências de Pass-Through Incompleto da Taxa de Juros, Crédito Direcionado e Canal de Custo da Política Monetáriano Brasil. Estudos Econômicos, 48, 559-595. https://doi.org/10.1590/0101-41614841inj

Souza Sobrinho, N. (2003). Uma avaliação do canal de crédito no Brasil. Banco Nacional de DesenvolvimentoEconômico e Social.

Takeda, T., Rocha, F., \& Nakane, M. I. (2005). The Reaction of Bank Lending to Monetary Policy in Brazil. Revista Brasileira de Economia, 59, 107-126. https://doi.org/10.1590/S0034-71402005000100005

Toda, H. Y., \& Yamamoto, T. (1995). Statistical Inference in Vector Autoregressive with Possibly Integrated Processes. Journal of Econometrics, 66, 225-250. https://doi.org/10.1016/0304-4076(94)01616-8

Tomazzia, E. C., \& Meurer, R. (2009). O mecanismo de transmissão da política monetária no Brasil: Uma análise em VAR por setor industrial. Economia Aplicada, 13, 371-398. https://doi.org/10.1590/S1413-80502009000400002

Torres Filho, E. T. (2006). Crédito direcionado e direcionamento do crédito: Situação atual e perspectivas. Revista do BNDES, 13, 35-50.

Veiga, M. G., \& McCahery, J. A. (2019). The Financing of Small and Medium-Sized Enterprises: An Analysis of the Financing Gap in Brazil. European Business Organization Law Review, 20, 633-664. https://doi.org/10.1007/s40804-019-00167-7

Yamada, H., \& Toda, H. (1998). Inference in Possibly Integrated Vector Autorregresive Models: Some Finite Sample Evidence. Journal of Econometrics, 86, 55-95.

https://doi.org/10.1016/S0304-4076(97)00109-7 


\section{Appendix A. Graphs of the Impulse-Response Functions Involving DC.}
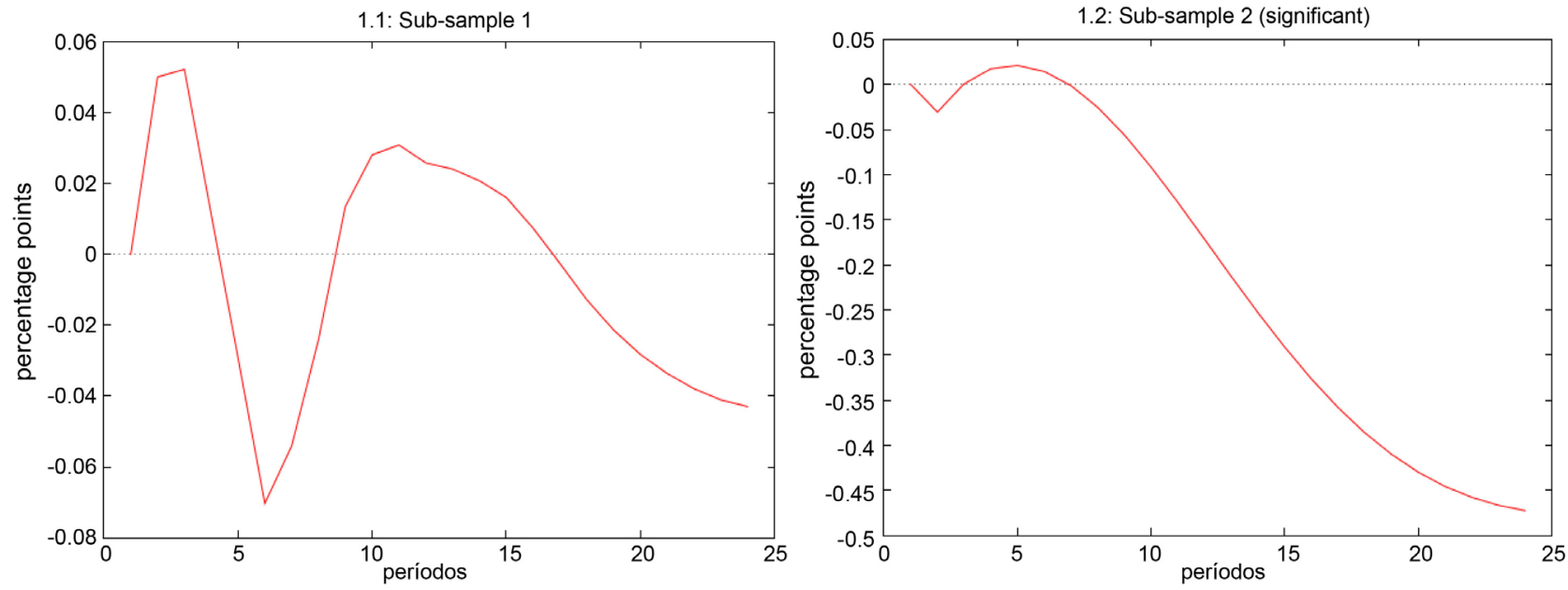

Figure A1. Response of GDP to a DC shock in the GM. Source: Elaborated by the authors.
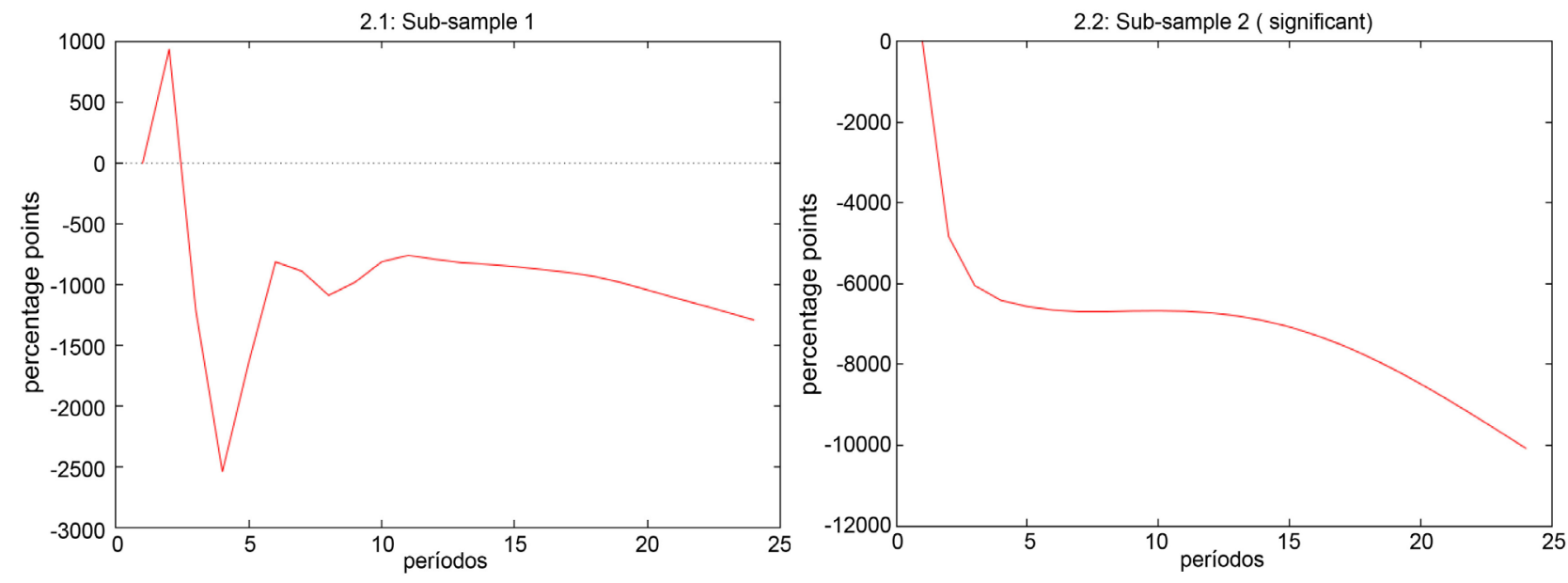

Figure A2. Response of FC to a DC shock in the GM. Source: Elaborated by the authors.
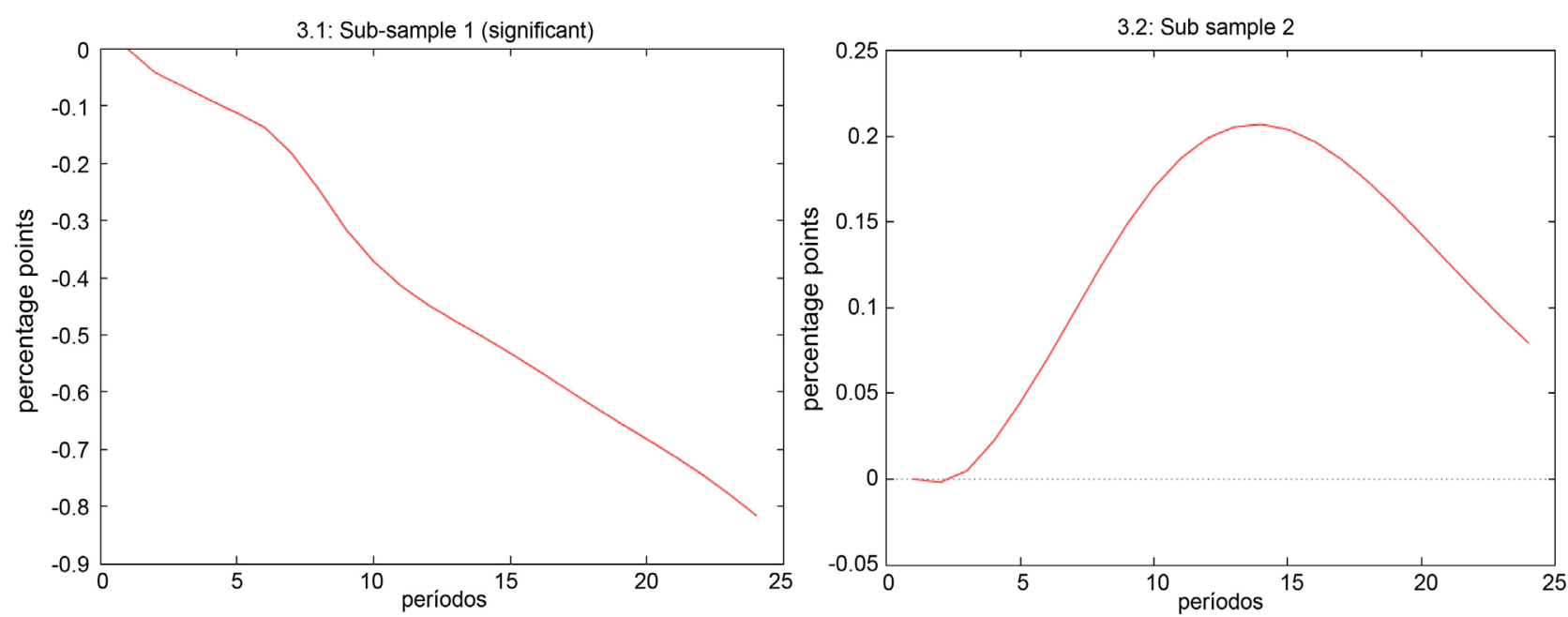

Figure A3. Response of SELIC to a DC shock in the MEA. Source: Elaborated by the authors. 

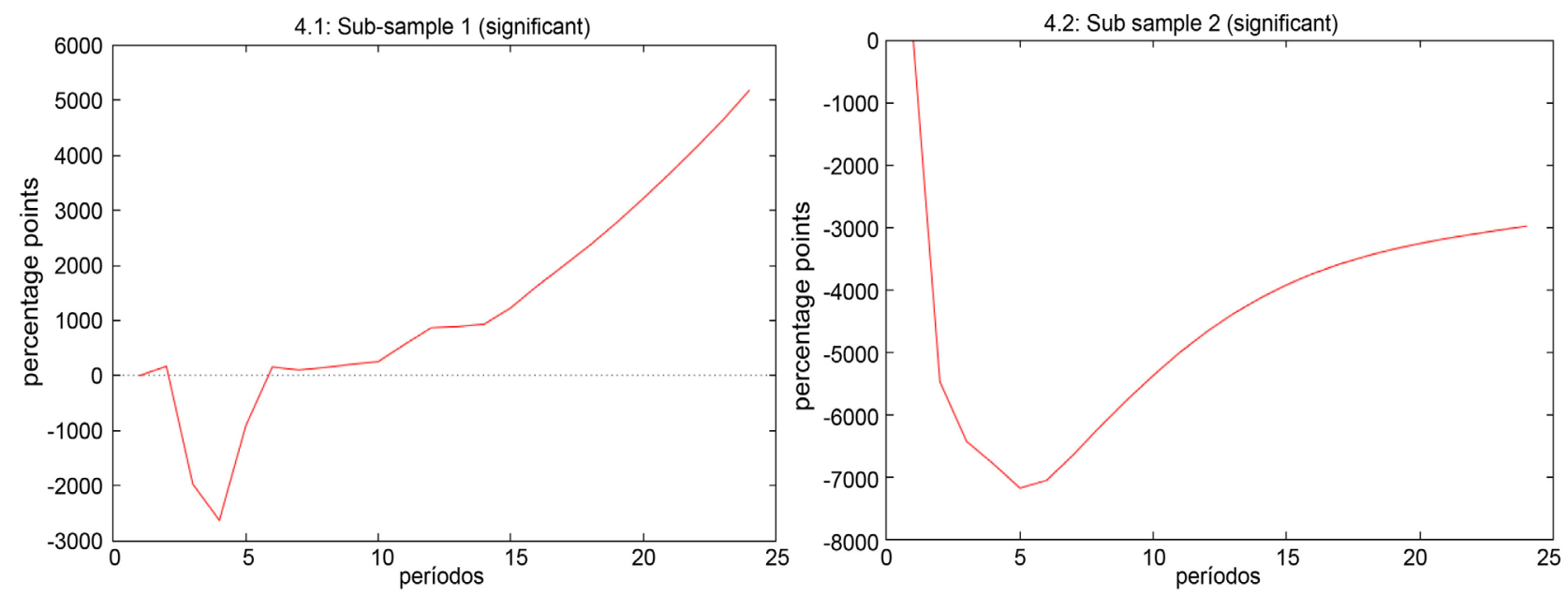

Figure A4. Response of FC to a DC shock in the MEA. Source: Elaborated by the authors.
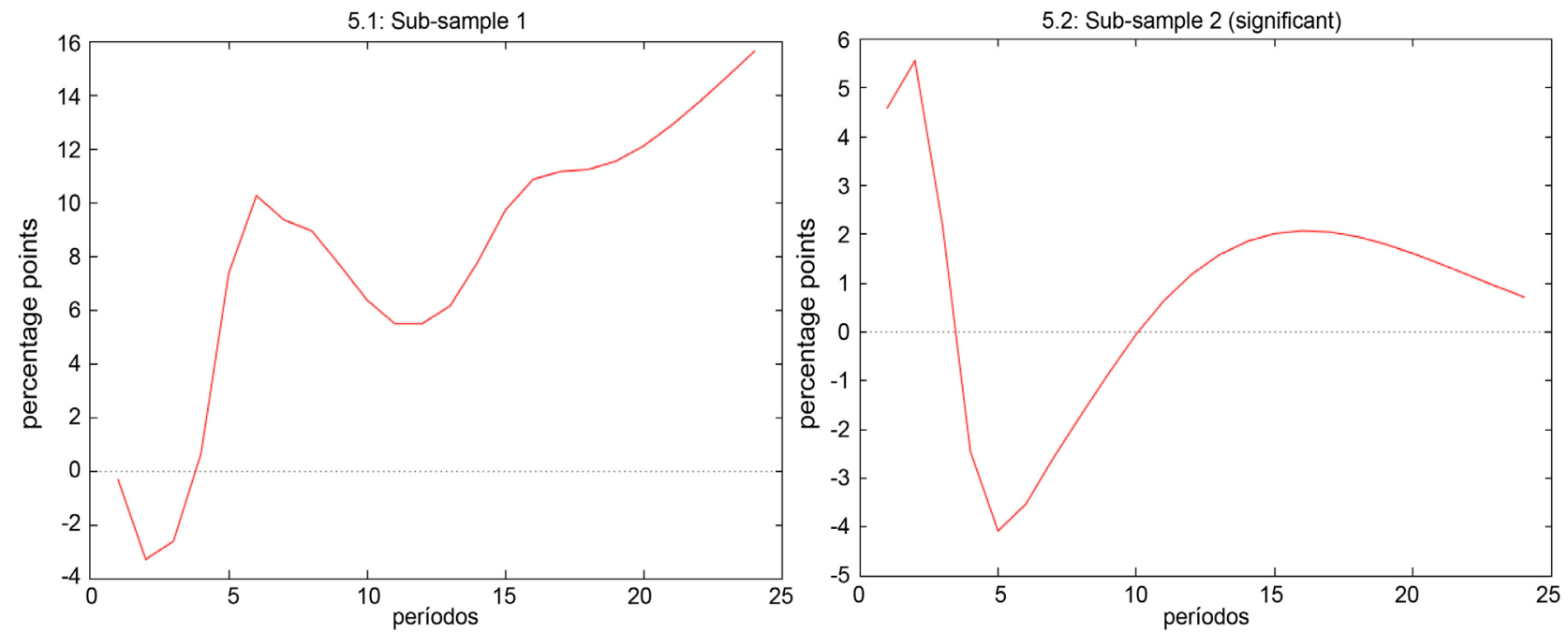

Figure A5. Response of EMBI to a DC shock in the MEA. Source: Elaborated by the authors.
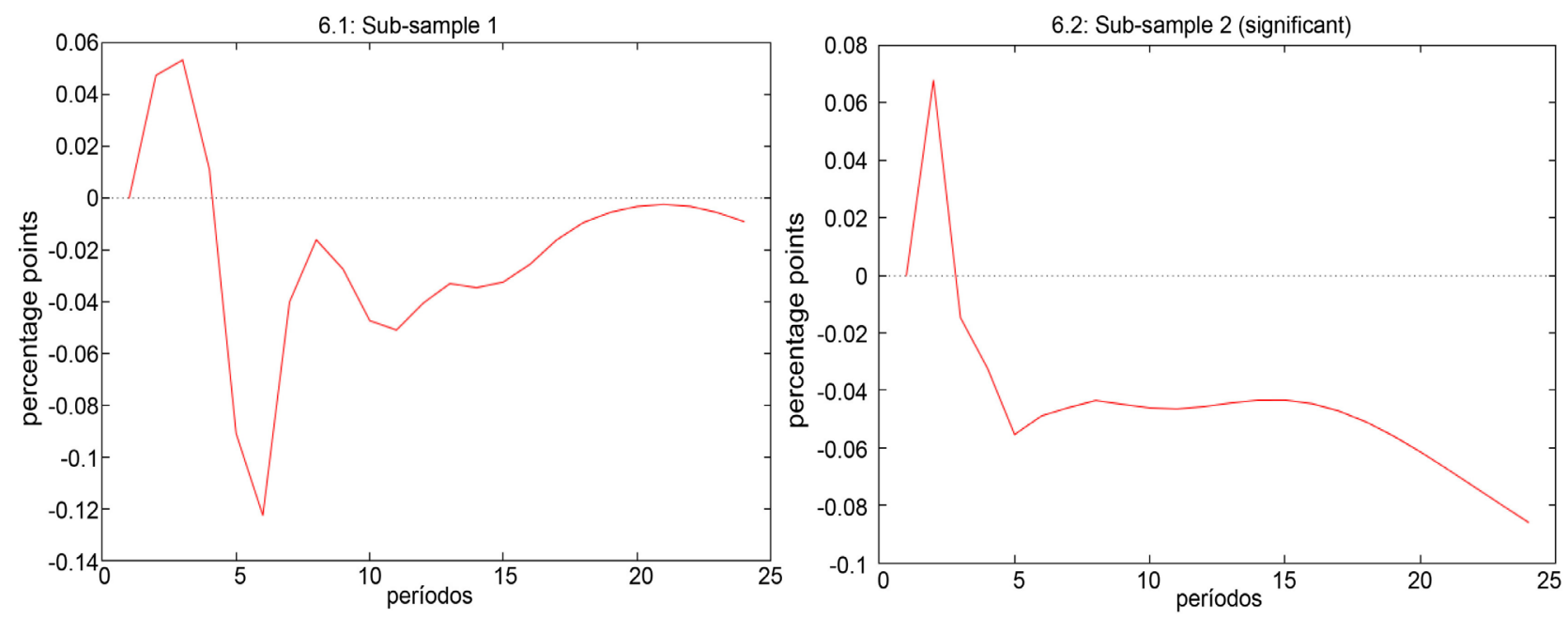

Figure A6. Response of GDP to a DC shock in the ME. Source: Elaborated by the authors. 

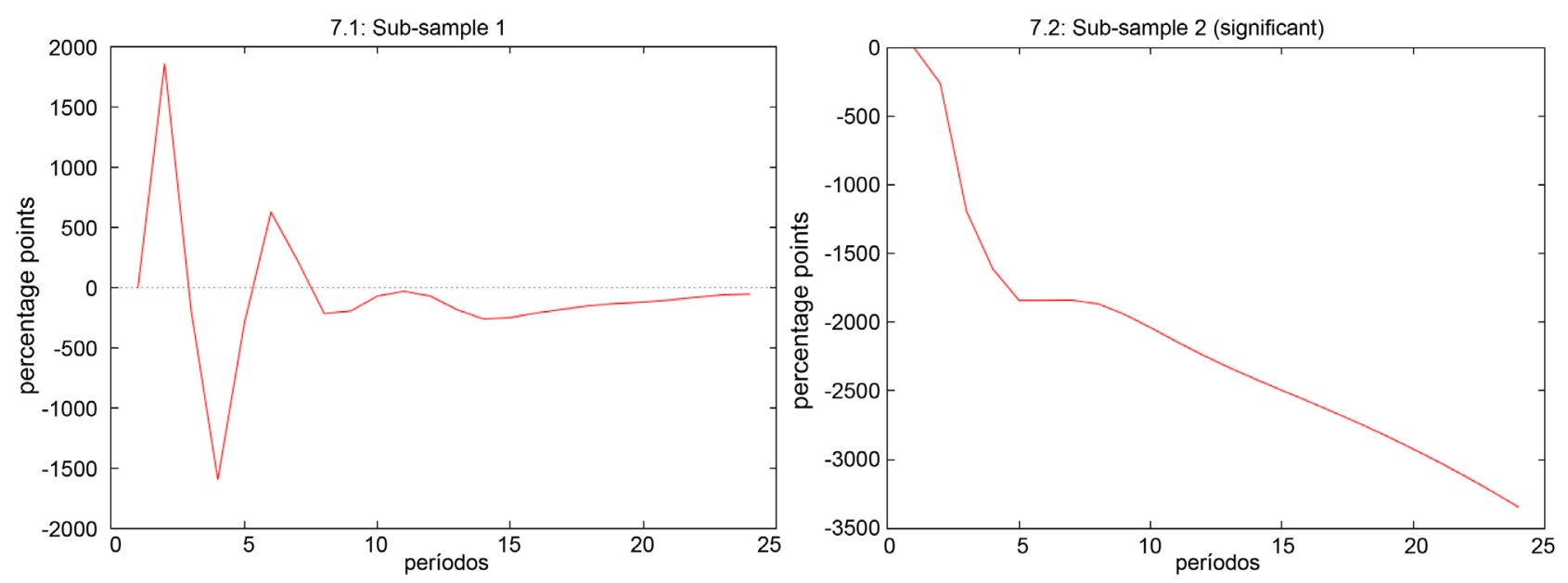

Figure A7. Response of FC to a DC shock in the ME. Source: Elaborated by the authors.
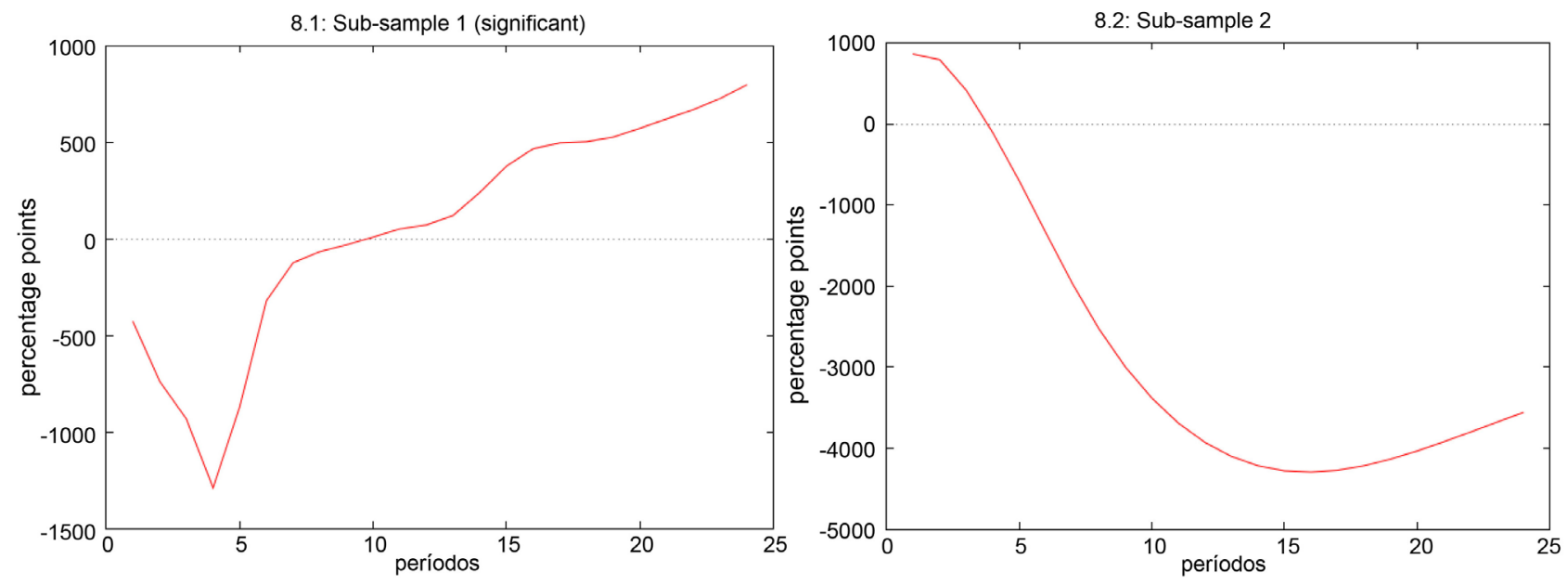

Figure A8. Response of DC to a SELIC shock in the MEA. Source: Elaborated by the authors.
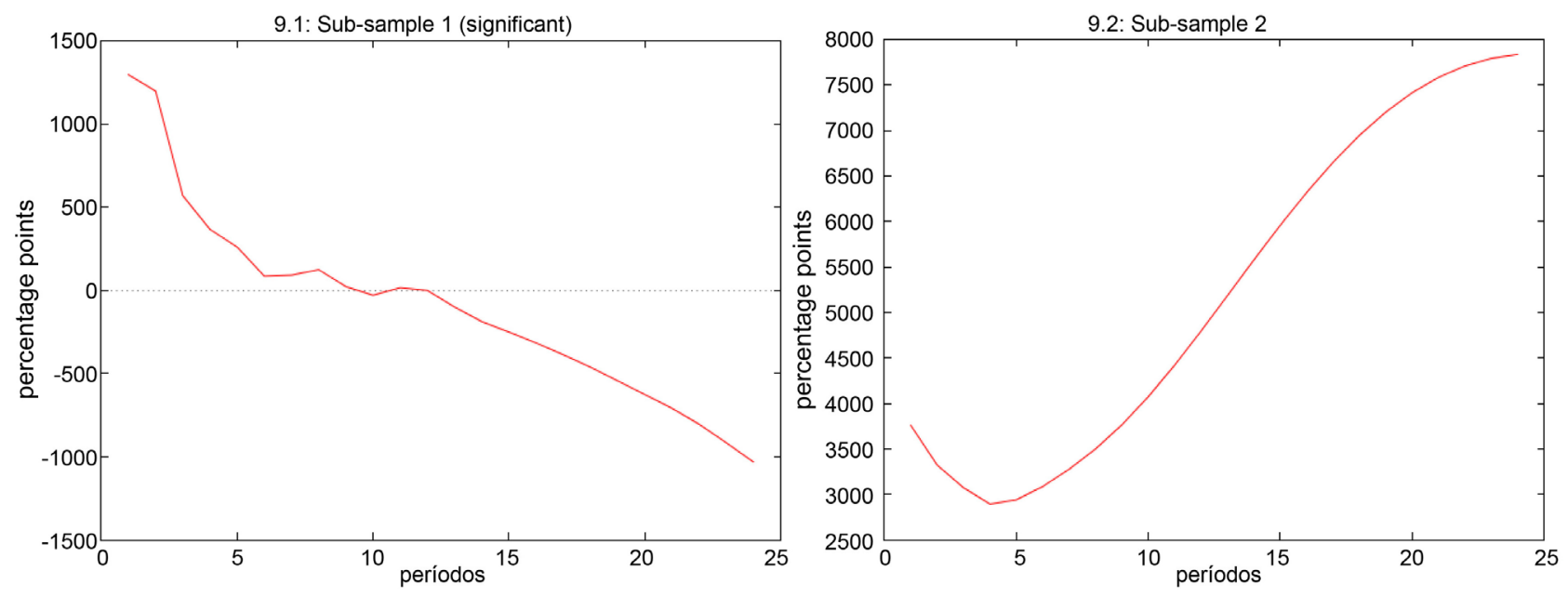

Figure A9. Response of DC to an FC shock in the MEA. Source: Elaborated by the authors. 